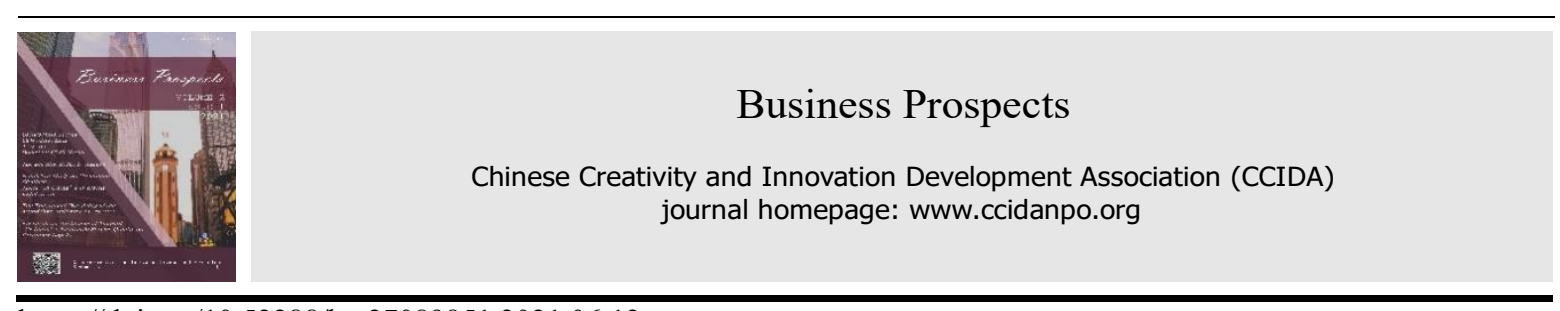

https://doi.org/10.52288/bp.27089851.2021.06.12

\title{
The Objectification of Miranda in The Collector
}

\author{
Hong Chang 1, * \\ ${ }^{1}$ Associate Professor of School of English Language and Culture, Xiamen University Tan Kah Kee College; \\ *Correspondence: rainbow@xujc.com
}

Received: 2021.02.18; Accepted: 2021.05.13; Published: 2021.06.01

\begin{abstract}
The objectification of women is the crime impossible to obliterate committed by the patriarchal society. It is essentially the denial of human equality. The Collector of John Fowles presents a tragedy of human nature, in which the interweavement of explicit and implicit objectifications reduces women to an inhuman condition and deprives them of life and freedom. This novel implies strong awareness of social criticism and bears realistic significance.
\end{abstract}

Keywords: The Collector; John Fowles; Objectification; Patriarchal Society

The novel is about a lonely young man, Frederick Clegg, who works as a clerk in a city hall, and collects butterflies in his spare time. The first part of the novel tells the story from his point of view.

Clegg is obsessed with Miranda Grey, an upper-class art student. He admires her from a distance, but is unable to make any contact with her because of his nonexistent social skills. One day, he wins a large prize in the pools. This makes it possible for him to stop working and buy an isolated house in the countryside. He feels lonely, however, and wants to be with Miranda. Unable to make any normal contact, Clegg decides to add her to his 'collection' of pretty, petrified objects, in hopes that if he keeps her captive long enough, she will grow to love him. After careful preparations, he kidnaps Miranda using chloroform and locks her up in the cellar of his house. He is convinced that Miranda will start to love him after some time. However, when she wakes up, she confronts him with his actions. Clegg is embarrassed, and promises to let her go after a month. He promises to show her "every respect", pledging not to sexually molest her and to shower her with gifts and the comforts of home, on one condition: she can't leave the cellar.

Clegg rationalizes every step of his plan in cold, emotionless language; he seems truly incapable of relating to other human beings and sharing real intimacy with them. He takes great pains to appear normal, however, and is greatly offended at the suggestion that his motives are anything but reasonable and genuine.

The second part of the novel is narrated by Miranda in the form of fragments from a diary that she keeps during her captivity. Clegg scares her, and she does not understand him in the beginning. Miranda reminisces over her previous life throughout this section of the novel, and many of her diary entries are written either to her sister, or to a man named G.P., whom she respected and admired as an artist. Miranda reveals that G.P. ultimately fell in love with her, and subsequently severed all contact with her. Through Miranda's confined reflections, Fowles discusses a few philosophical issues, such as the nature of art, humanity, and God (Loveday, 1985).

At first Miranda thinks that Clegg has sexual motives for abducting her, but as his true character begins to be revealed, she realizes that this is not true. She starts to have some pity for her captor, comparing him to Caliban in Shakespeare's play The Tempest because of his hopeless obsession with her. Clegg tells Miranda that his first name is Ferdinand (eventual winner of Miranda's affections in The Tempest).

Miranda tries to escape several times, but Clegg is always able to stop her. She also tries to seduce him in order to convince him to let her go. The only result is that he becomes confused and angry. When Clegg keeps refusing to let her go, she starts to fantasise about killing him. After a failed attempt at doing so, Miranda passes through a phase of self-loathing, and decides that to kill Clegg would lower her to his level. As such, she then 
refrains from any further attempts to do so. Before she can try to escape again, she becomes seriously ill and dies, probably of pneumonia.

The third part of the novel is again narrated by Clegg. At first, he wants to commit suicide after he learns of Miranda's death, but after he reads in her diary that she never loved him, he decides that he is not responsible and is better off without her (Neary, 1988). Finally, he starts to plan the kidnapping of another girl.

A great work always reveals or manifests some common things in human life to some extent, but this kind of things are always hidden in the inside rather than out. Readers can only understand the truth by digging deeply into the work. The Collector is such a work that reveal the crime of patriarchal society, besides the maltreat, humiliation, the most prominent characteristics is the objectification of women. The author believes that one of the deep connotations of the works is that it touches and exposes the evil of bullying and strangling women in the patriarchal society, and the prominent expression of this evil is the objectification of women.

At the very beginning, it is necessary to define the concept of "reification" which originates from Hungarian Marxist theorist Georg Lukacs (Oilman, 1973; Fromm, 2004). Lucas uses this conception to analyze the capitalist world, to reflect upon the social revolution. In his mind, in the fully developed economic market, human behavior has been departed from human being and turned into a kind of commodity. It assumes objectivity as those non-human objects. Lost his dominant position, human being is obliged to sort of commodity which is subject to the market operation rules.

In a way, "reification" can be taken as a synonym of commercialization. However, from the sexual point of view, this concept does not strike a balance between man and woman, neither does it has a close relationship with the social system. Because in the male-dominated society, woman is more likely to be objectified into a kind of commodity. In this context, the identity of woman is defined as material for barter and becomes a "market woman" French feminist pioneer Simone de Beauvoir pointed out that (The Second Sex, 1949) after the emergence of private ownership women's fate has always been closely linked with the private property. The female always exists as alienated goods. In English literature, women as a commodity to be exchanged in a market find its representation in Thomas Hardy's novel The Mayor of Casterbridge. At the very beginning of the novel, Harchard sold his wife and little daughter for five gold coins. Besides taking women as commodity, patriarchal society regards women as personal belongs, which is object rather than human. This kind of objectification is less straightforward but rather sub-rosa. Some instances could be found in Shakespeare's Othello and Vladimir Nabokov's Lolita. Whatever objectification it is, the essence is a denial of the equal relationship between male and female.

Objectification is an evil imprint which can be hardly erased in a society dominated by man. In The Collector, both visible and invisible objectification combined together and under such kind of circumstances, the heroine is put under inhuman situation. In this tragic story, Miranda is objectified by Clegg in the following way:

\section{Miranda as Housed Collection}

First of all, woman was regarded as housed collections. The story begins with Clegg spying on and kidnapping Miranda. For Clegg, Miranda is tantamount to a butterfly waiting to be captured. He often records the activities of Miranda in his diary, taking her as a quarry to be collected. "seeing her always made me feel like I was catching a rarity, going up to it very careful, heart-in-mouth as they say. A Pale Clouded Yellow, for instance. I always thought of her like that, I mean words like elusive and sporadic, and very refined-not like the other ones, even the pretty ones. More for the real connoisseur" (C:1). He often stands by the window to peep at her at the daytime. In the evening Clegg marks Miranda in his observation diary, at first with X, and then when he knows her name, he uses M. The way he portrays Miranda is similar to he does butterflies. In his eyes, Miranda's long pigtail is "very pale, silky, like Burnet cocoon." (C:7) Then he embarks on his plan to collect Miranda. He buys a van and a house in the country with an enclosed room in its basement that he remodels to make securable. When he returns to London, Clegg watches Miranda for ten days. Then, as she is walking home alone from a movie, he captures her, using a rag soaked in chloroform, like massacring butterflies, ties her up in his van, takes her to his house, and locks her in the basement room. In Clegg's narration, he specifies this collecting action (Pollheide, 2003). "It's finally ten days later happened as it sometimes does with butterflies. I mean you go to a place where you know you may see something rare and you don't, but the next times not looking for it you see it on a flower right in front of you, handed to you on a plate, as they say." (C:24) "That night was the best thing I ever did in my life (bar winning the pools in the first place). It was like catching the Mazarine Blue again or a Queen of Spain Fritillary.” (C:29) Some critics point out that the relationship between 
Clegg and Miranda is like the relationship between colonialist and the people under colonial rule. To Clegg, Miranda is merely part of his property and territory (Salami, 1992).

When Miranda was hold in captivity, Clegg is barbaric, cruel, greedy, tyrannical, selfish and hypocritical. $\mathrm{He}$ often uses his colleting logic to deal with the relationship with Miranda. He created a country without freedom in which he is a brutal ruler imposing tyrannical dictatorship on Miranda. Miranda becomes a victim of his sadistic free will. He rules Miranda as an item of collection. Miranda had a clear awareness of her tragic fate and Clegg's crime and points out "I am one in a row of specimens. It's when I try to flutter out of line that he hates me. I'm meant to be dead, pinned, always the same, always beautiful. He knows that part of my beauty is being alive, but it's the dead me he wants me living-but-dead. I felt it terribly strong today. That my being alive and changing and having a separate mind and having moods and all that was becoming a nuisance. (C:189). Collection and possession is Clegg's life credo. He says: "What she never understood was that with me it was having. Having her was enough. Nothing needed doing. I just wanted to have her and safe at last (C:91). What Clegg interested in is possess safely.

Eventually he did not really get her, because she was not a living person, but a corpse, like a butterfly specimen without the beauty of life. However, Clegg learned nothing from his experience with Miranda, he attributed his failure to "too high a goal". After Miranda's death, he buried her and made a fire to dry the room, planning to meet the next "guest", which would be a female clerk expected to be easily tamed. Such a cold end made us tremble with fear, it's hard to imagine how many girls will suffer the same tragedy as Miranda.

\section{Miranda as the Target}

Taking women as the target to satisfy men's sexual desire. Clegg is a metamorphic madman for sexual desire. He thinks that the activeness in sex is men's privilege and women should only be the passive receiver. When Miranda tried to use active sex to influence him, he was irritated because his privilege of activeness was threatened: "I was like mad when I got out. I can't explain. I didn't sleep the whole night. It kept on coming back, me standing and lying there with no clothes on, the way I acted and what she must think. I could just see her laughing at me down there. Every time I thought about it, it was like my whole body went red (C:98). From then on, Clegg treats Miranda as a degrading prostitute, then provided excuses for his mistreating Miranda in a later time: "I could have done anything. I could have killed her. All I did later was because of that night (C:98). Towards Miranda's revolts, Clegg overwhelmed her many times by narcotic, shot her naked pictures, and masturbated when holding these pictures: "The photographs (the day I gave her the pad), I used to look at them sometimes. I could take my time with them. They didn't talk back at me (C:98). To Clegg, these pictures are no difference from the substitute of Miranda's absence. To be frank, these pictures are the tools for Clegg to satisfy his sexual desire. From the process of shooting pictures and relishing with these pictures, Clegg tastes incomparable pleasure.

Except for Clegg, the other manipulating male agent of Miranda is George Paston. The main content of Miranda's diary is related to him. He plays an important role in Miranda's life. He is portrayed to be a middleaged man who is a painter and mentor whom Miranda admires. G.P.'s game of dominating women seems to be through his seduction, and when they feel pity for him, he exploits them. He deploys the same method of sleeping deliberately with Miranda's friend Anttoinette in order to teach, "exorcize" Miranda. G.P.'s irresponsible promiscuity represents an acceptance of life and his own sexuality; his motto, one feels, might be Luther's 'Sin boldly'. According to Freud, this ideal longing for promiscuity constitutes the most radical form of "pleasure principle", where all tensions are reduced and all difference are abandoned.

G.P. is the man who holds the androcentric perspective. He is a representative of androcentrism, a patriarchal institution (including, in a Rawlsean sense, those policies, practices, positions, offices, roles and expectations) and behaviors which give privilege (high stats, value, prestige) and power(power-over) to males or to what historically is male-gender identified, as well as a sexist conceptual framework needed to sustain and legitimize it. An androcentric perspective not only marginalizes and excludes woman but denies her very existence, defining what it sees of her as what she is not. Woman is the "other", the deviant, the aberration. Woman is not man. This perspective renders women not only unknown, but virtually unknowable. Most of Miranda's diary is about G.P., he occupies most of Miranda's life. He is a middle-aged man who is a painter and mentor Miranda admire. He thinks that women are a "disease" whose name he cannot reveal since "you don't tell diseases their name". G.P.'s dominates women mainly through his seduction, when they feel pity for him, he exploits him. In addition, G.P. impresses philosophy of life and art on Miranda in order to control her completely. He impinges on most of what Miranda does and thinks. Miranda even evaluates Clegg in G.P.'s 
opinion. She says "he makes me want to dance round him, bewilder him, dazzle him, dumbfound him...The hateful tyranny of weak people G.P. said it once." (C:120) Both of Miranda's behavior and attitude towards Clegg are borrowed from G.P., who has taught her well to dazzle and confound by his own example. G.P. criticizes her work "It hurt like a series of slaps across the face" (C:147). She employs the same harsh words to criticize Clegg "like continually slapping someone across the face". As Miranda herself thinks back over the teaching of G.P. (some of which take the forms of rules to live by) she wonders, "How many times have I disagreed with him? And then a week later with someone else I find I'm arguing as he would argue. Judging people by his standards" (C:134). Then G.P. is the typical representative of androcentrism. Woman for him is just the object to satisfy his sexual desire. He tells Miranda that "I like bed, I like the female body, I like the way even the shallowest of women become beautiful when their clothes are off $[\ldots]$ the one time you see it is when a woman takes her clothes off and cannot look you in the eyes (as I couldn't then). Just that first Botticelli moment of the first time of her taking her clothes off. Soon shrivels. The old Eve takes over. The strumpet. Exit Anadyomene" (C:164). He often imposes his idea on Miranda and affects her views towards both life and art without caring about her feelings. Furthermore, his idea conveys the androcentrism and passes to Miranda through a male channel.

\section{Miranda as the Merchandise}

The merchandise of women is expressed by the profession as prostitutes, for the reason prostitute is pure merchandise in eroticism market. After winning the pool, Clegg finds a prostitute to have a fun, but he feels depressed for her oldness. "she was old and she was horrible, horrible. I mean, both the filthy way she behaved and in looks" (C:12). In order to put down Miranda for her "seduce action", Clegg says to her ironically: "You're no better than a common street-woman, [...] I could get a lot more expert than you in London. Any time. And do what I liked". (C:102) The word "street-woman" expresses Clegg's curse and insult to Miranda, and regards her as "merchandise". In addition, the merchandise of women is embodied by its substitution-erotic magazine and books. At the beginning of the novel, Clegg mentions: “...was I started to get interested with some of the books you can buy at shops in Soho, books of stark women and all that (C:13). After the "seduce action", Clegg always buys some to satisfy his "male gaze", "there was one of the books called Shoes with very interesting pictures of girls, mainly their legs, wearing different sorts of shoes, some just shoes and belts they were really unusual pictures, artistic (C:103). This example depicts clearly that erotic pictures is nonhuman, in addition, what it adepts in is not to express the whole person but the parts of the body. Clegg doesn't realize his objectification to Miranda, he tries to decorate and cover his brutal behaviors. He calls his "prisoner" as "guest", as a matter of fact, he deprives Miranda's freedom harshly; He promises to set Miranda free many times, but he failed to do so every time. Miranda becomes faded after she loses her freedom, and is seriously ill with pneumonia, he hesitates to bring a doctor to the house. His delay indirectly causes Miranda's death. But he defends for himself that "I thought I was acting for the best and within my rights" (C:108). The cause of the tragedy is Clegg considers the world to be full of objects designed to gratify his desires. Increasingly desperate, Miranda tries to kill Clegg with an axe he has left out when he is escorting her to take a bath upstairs. She injures him, but he is able to prevent her from escaping. Finally, she tries to seduce him, but he is unable to respond, and leaves, feeling humiliated. He pretends that he will allow her to move upstairs, with the stipulation that she must allow him to take pornographic photographs of her. She reluctantly cooperates, and he immediately develops the pictures, preferring the ones with her face cut off. He treats butterfly and especially Miranda as objects of his own interests. He feels that he has power and authority over them. He doesn't see butterfly and Miranda as themselves but otherness, no voice and no identity. This conforms to the theme of the fiction, male domination of the female.

\section{Miranda as the Incarnation of Butterfly}

Miranda shares many similarities with the butterflies Clegg collected. In other word, she is the incarnation of the butterfly. So she is doomed to be imprisoned and killed by Clegg. What Miranda needs most is not the beautiful clothes and money and freedom, air and light. She tells Clegg: "The air, I cannot breathe at nights, I've woken up with a headache. I should die if you kept me here long" (C:36). Later she refuses to eat anything merely to exchange some terms with Clegg. She says "I can't live all the time down here. I must have some fresh air and light" (C:44). Moreover, we can find some clues in Miranda's diary. "Does the world go on? Does the sun still shine?" (C:117) "I miss the fresh air. The thing I miss the most is fresh light. I cannot live without light" (C:117). Miranda is very excited after Clegg takes her upstairs. Even in the condition that Clegg bundles 
her hands and gaps her mouth. Clegg describe that situation with the following words. "I took her arm tight and let her stand there for five minutes. I could hear her breathing deep" (C:47). Miranda also records that experience in her diary. "First the outsider air, being in a space bigger than ten by ten by twenty (I have measured it out), being under the stars, and breathing wonderful, even though it was damp and misty, wonderful air" (C:118) After walking outside, she will exchange her feeling with Clegg "All the time I was breathing in beautiful outdoor air. That was good, so good I can't describe it. So living, so full of a plant smells and country smells and the thousand mysterious wet smells of the night" (C:129) "A lovely night-walk. There was great reaches of clean sky, no moon, sprinkles of warm white stars everywhere, like milky diamonds, and a beautiful wind. From the west, I made him take me round and round, ten or twelve times. The branches rustling, an owl hooting in the wood. And the sky all wild, all free, all wind and space and stars" (C:169) "A pale grey sky. I saw birds fly across, pigeons, I think. I heard outside sounds. This is the first proper daylight I've seen for two months. It lived. It made me cry" (C:229). Both butterflies and Miranda are daughters of nature, they cannot live without freedom, air and light.

\section{Conclusion}

The Collector is a tragedy of women's objectification. Miranda's miserable fate disposes the crime of the patriarchal society with an intense social critical consciousness. John Fowles, a male writer, regards women should be an individual, not the object (Wolfe, 1979; Huffaker, 1980; Barnum, 1988; Aubrey, 1991). Unfortunately, objectification prevails in every corner of the society after the publication of the novel forty years after, the objectification of women is even serious under the veil in public media and other social sphere without any notification. To women, another "God", the patriarchal society, even recessed, still be the dominance of women even human's bondage, limits their ideology influences their behavior. The author thinks the present concern of The Collector is to raise the concern of the women, inspire the human nature. With Nidetch's announcement of the death of the God, the Almighty has deceased from the human life with the coming of human's own control of their lives. Objectification to women is the crime in the patriarchal society, it is not one day's effort to erase the influence of the male. It is quite natural for man to deny or ignore their forces, whereas females are the natural to be sacrifice to the efforts of men without any consciousness, this is psychological recognition or natural objectification. The core of objectification is not who is the hero (for one day men will be the concern of objectification by women), the focus is both sides should treat the opposite sex as a whole individual, someone with unique personality, freedom, choices, as well as rights, dependence and subjectivity.

On the analysis above, both sides should exchange their position with the opposite sex, try to notice and understand their inner world, make a wise and fittest response, to say, men and women had better form a harmonious, win-win relationship if they could give more comfort and caring to the opposite sex, hope to build a mutual wish and target to form a harmonious world.

\section{Reference}

1. Aubrey, J. R. (1991). John Fowles: A Reference Companion. Westport: Greenwood Press.

2. Barnum, C. M. (1988). The Fiction of John Fowles: A Myth of Our Time. Greenwood, Florida: The Penkevill Publishing Company.

3. Loveday, S. (1985). The Romances of John Fowles. New York: St. Martin's Press.

4. Fowles, J. (1963). The Collector. London: Jonathan Cape Ltd.

5. Fromm, E. (2004). Marx's Concept of Man. New York: Continuum International Publishing Group Ltd.

6. Huffaker, R. (1980). John Fowles. Boston: Twayne Publishers.

7. Neary, J. M. (1988). John Fowles's Clegg: A Metaphysical Rebel. Essays in Literature, 15(1): 48-60.

8. Oilman, B. (1973). Alienation: Marx's Concept of Man in Capitalist Society. New York: Cambridge University Press.

9. Onega, S. (1989). Form and Meaning in the Novels of John Fowles. London: U. M. I. Research Press.

10. Pollheide, von Jens. (2003). Postmodernist Narrative Strategies in the Novels of John Fowles. Bielefeld University.

11. Salami, M. (1992). John Fowles's Fiction and the Poetics of Postmodernism. London \& Toronto: Associated University Press.

12. Wolfe, P. (1979). John Fowles: Magus and Moralist. London: Bucknell University Press. 